\title{
Human Capital and Economic Growth in Indonesia
}

Mu'is Fanani, Cahya Budhi Irawan

(STIE Jaya Negara Tamansiswa Malang)

\begin{abstract}
This study examines government investment in education and health, as well as job opportunities as reflected in work participation and its impact on economic growth by using secondary data from world banks using the moving average autoregression method. We find that work participation, education investment and health investment positively related to economic growth.
\end{abstract}

Keywords: Education Investment, Health Investment, Work Participation

\section{Background}

The ASEAN economy continues to grow and develop well before COVID-19 hits ASEAN in 2020. ASEAN Plus Three cooperation with Japan, China and South Korea encourage economic growth in ASEAN with a large population and abundant natural resources. ASEAN has sufficient resources to grow economically (Chen \& Kimura,2019). Indonesia is one of the ASEAN member countries with a very large population. Indonesia has a population of more than200 million people. Such a large population is a resource that must be managed properly in order to participate in economic development (Tay \& Tijaja,2017).

To create a strong economy, of course, it must be supported by superior human resources. Modern human resource management makes human capital a performance driving factor and a very valuable asset for modern humans today. To encourage economic growth and rise during a pandemic, of course, education is not enough, health factors and access to employment are needed to increase work participation (Casademunt,2016). This study examines these three factors, namely investment in education, investment in health and job opportunities, which are reflected in work participation and their impact on economic growth using secondary data from word banks.

\section{Literature Review}

The population is a valuable human resource that needs to be managed and developed properly through education, health services and job opportunities. Residents can participate in economic growth through the real sector where residents can become investors, business managers and employees. When the population optimally participates in the economy, the economy can grow and develop properly (Dames, 2020).

Indonesia is a country with a very large population which is a strength in its own right. The large population means abundant human resources. However, the population must also be balanced with 
human capital owned by the population so that it can make the population productive and contribute to the economy (Shambaugh,2020). The population can provide the opportunity to increase the economy with a very large market and an abundant workforce. Of course, after having sufficient human capital to create added economic value. So it is necessary to understand that the population is one of the country's most valuable assets (Oberman,2012).

\section{Research Method}

This study examines government investment in education and in the health sector, as well as job opportunities as reflected in work participation and its impact on economic growth by using secondary data from world banks using the moving average autoregression method with the following equation:

$\mathrm{GDPt}=\mathrm{Ct}+\beta 1 \mathrm{LPt} 1+\beta 2 \mathrm{EI} 2+\beta 3 \mathrm{HI} 3+$ et

Where,

GDP = Economic Growth

$\mathrm{C}=$ Constanta

$\mathrm{LP}=$ Labor Force Participation

$\mathrm{EI}=$ Education Investment

$\mathrm{HI}=$ Health Investment

$\mathrm{e}=$ Term Error

\section{Result and Discussion}

The estimation results are as follows:

$\mathrm{GDP}=-3.95200662454 \mathrm{e}+12+45402319843.2 * \mathrm{EI}+6639715823.4 * \mathrm{HI}+59389338724.4 * \mathrm{LP}$

From the estimation results of work participation (LP), education investment (EI) and health investment (HI) are positively related to economic growth. which is briefly described in Table 1 which describes the estimation results as follows:

Table 1. Estimation Results

\begin{tabular}{|l|l|l|l|l|}
\hline Variable & Coefficient & Std. Error & t-Statistic & Prob. \\
\hline C & $-3.95 \mathrm{E}+12$ & $1.73 \mathrm{E}+12$ & -2.290152 & 0.0359 \\
\hline EI & $4.54 \mathrm{E}+10$ & $4.00 \mathrm{E}+10$ & 1.13629 & 0.2726 \\
\hline HI & $6.64 \mathrm{E}+09$ & $5.67 \mathrm{E}+08$ & 11.71666 & 0 \\
\hline LP & $5.94 \mathrm{E}+10$ & $2.60 \mathrm{E}+10$ & 2.284551 & 0.0363 \\
\hline R-squared & 0.981165 & Mean dependent var & $2.03 \mathrm{E}+12$ \\
\hline Adjusted R-squared & 0.977633 & S.D. dependent var & $7.30 \mathrm{E}+11$ \\
\hline S.E. of regression & $1.09 \mathrm{E}+11$ & Akaike info criterion & 53.84667 \\
\hline Sum squared resid & $1.91 \mathrm{E}+23$ & Schwarz criterion & 54.04581 \\
\hline Log likelihood & -534.4667 & Hannan-Quinn criter. & 53.88554 \\
\hline F-statistic & 277.8266 & Durbin-Watson stat & 1.112105 \\
\hline
\end{tabular}

Based on the estimation results described in Table 1., it can be seen that the R-square is very high so that changes in employment, education and health in the community change the economic growth significantly which can be predicted in the study period in Figure 1 as follows: 


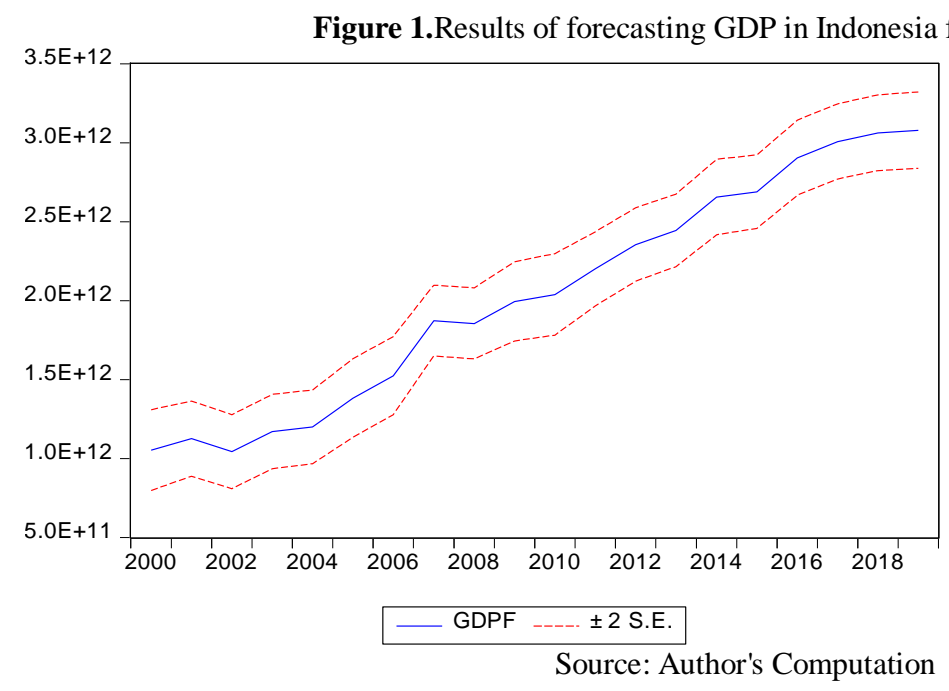

Based on the forecast results in Figure 1, Indonesia's GDP before the corona pandemic took place tended to increase and the management of human resources, especially in human capital investment in Indonesia, also improved from year to year. This can be seen from the increasing graph which indicates that the Indonesian economy is healthy, education and health also contribute positively and community work participation in economic growth also continues to increase.

\section{Conclusion}

The population is an important asset for the country and needs to be managed properly. Education, health and work participation or employment opportunities are three things that need to be maintained and developed through human capital investment so that the population can make the best contribution to their country.

\section{Reference:}

Casademunt, A.M.L.(2016).Strategic Labor Relations Management in Modern Organizations. Hershey : IGI Global

Chen,L., Kimura,F.(2019).Developing the Digital Economy in ASEAN. London : Routledge

Dames,S., Luctkar-Flude,M. ,Tyerman,J.(2020).Edelman and Kudzma's Canadian Health Promotion Throughout the Life Span .Amsterdam : Elsevier

Oberman,R.(2012).The Archipelago Economy: Unleashing Indonesia's Potential. Chicago : McKinsey Global Institute

Shambaugh,D.(2020). Where Great Powers Meet: America and China in Southeast Asia. Oxford : Oxford University Press

Tay,S., Tijaja,J.P.(2017).Global Megatrends: Implications for the ASEAN Economic Community.Jakarta : ASEAN Secretariat 